\title{
CLONAL PROPAGATION OF NEEM (Azadirachta indica A. Juss.) VIA DIRECT AND INDIRECT IN VITRO REGENERATION ${ }^{1}$
}

Laureen Michelle Houllou ${ }^{2}$, Robson Antônio de Souza ${ }^{2}$, Elizabete Cristina Pacheco dos Santos², José Jackson Pereira da Silva ${ }^{2}$, Marta Ribeiro Barbosa ${ }^{2}$, Jean Philippe Guimarães Sauvé2 e Wolfgang Harand ${ }^{3}$

\begin{abstract}
The study was conducted with shoot tip explants of neem (Azadirachta indica A. Juss) to identify a viable regenerative process. Shoot tips were obtained from neem embryos cultured alternatingly in DKW medium supplemented with BAP and medium without hormones. Initial shoot development was influenced by cotyledon presence. Basal callus, excised from in vitro stem base, also presented organogenic potential. In some cases, plant lines, obtained from each seed, presented different characteristics. The most common characteristic observed in vitro was callus formation at the stem base. However, the rarest characteristics were stem callus formation and leaf senescence. The regenerated shoot tips were further subculture and rooted on a medium supplemented with IBA so that complete plants could be obtained. The rooted plants were transplanted to a greenhouse and successfully acclimatized. No significant differences in in vivo development were observed between neem plants from callus and from shoot tip propagation.
\end{abstract}

Keywords: Micropropagation; In vitro developmental characteristics; Callus organogenesis.

\section{PROPAGAÇÃO CONAL DE NIM (Azadirachta indica A. Juss.) VIA REGENERAÇÃO DIRETA E INDIRETA IN VITRO}

\begin{abstract}
RESUMO - O estudo foi realizado com explantes de ápices caulinares de nim (Azadirachta indica A. Juss) para identificar um processo viável de regeneração. Brotos foram obtidos a partir de embriões de nim cultivados alternadamente em meio DKW suplementado com BAP e meio sem hormônios. O desenvolvimento inicial dos brotos foi influenciada pela presença dos cotilédones. Calos basais, isolados in vitro a partir da base dos caules, também apresentam potencial de organogênese. Em alguns casos, as linhagens de plantas, obtidas a partir de cada semente, apresentaram características diferentes. A característica mais comum observada in vitro foi a formação de calos na base do caule. Entretanto, as características mais raras foram a formação de calo ao longo de todo o caule e a ocorrência de senescência foliar. Os apices caulinares regenerados foram posteriormente micropropagadados e enraizados em um meio suplementado com IBA, permitindo a obtenção de plantas completas. As plantas enraizadas foram transferidas para casa de vegatação e aclimatizadas com sucesso. Nenhuma diferença no desenvolvimento in vivo foi observada entre plantas obtidas de calos e da propagação de ápices caulinares de nim.
\end{abstract}

Palavras-chave: Micropropagação; Características do desenvolvimento in vitro; Organogêneses via calo.

\footnotetext{
${ }^{1}$ Recebido em 26.06.2013 aceito para publicação em 15.04.2015.

${ }^{2}$ Centro de Tecnologias Estratégicas do Nordeste, Recife, PE - Brasil. E-mail: <laureen.houllou@cetene.gov.br>, $<$ Robson.souza@cetene.gov.br>,<betesantos_bio@yahoo.com.br>,<jose.silva@cetene.gov.br>,<marta.barbosa@cetene.gov.br> e<jpgsauve@gmail.com>.

${ }^{3}$ Instituto Nacional do Semi-Árido, Campina Grande, PB - Brasil E-mail. E-mail: <wofgang.harand@cetene.gov.br>.
}

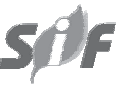

Revista Árvore, Viçosa-MG, v.39, n.3, p.439-445, 2015

http://dx.doi.org/10.1590/0100-67622015000300004 


\section{INTRODUCTION}

Neem, Azadirachta indica A. Juss. (Meliaceae Family) is a multipurpose tree from which many products can be obtained (insecticides, fertilizers and medicines). One of the main neem importace application is the production of highly effective, non-toxic insecticide. The azadirachtin $\mathrm{A}$ is recognized as strategically relevant for organic agricultural production. In fact, the USA and many Europian countries approved neem as an insecticide that can be safety use in organic production. As so, the interest on micropropagation of hight productive plants increase.

Neem has been conventionally propagated by seed but, it is recalcitrant in nature and rapidly loses seed viability. Furthermore, the heterozygous nature of neem are a significant problem in uniform plant selection of azadirachtin high-yielding and fast-growing trees from seedlings. As so, micropropagation technique can help the azadirachtin homogeneous production in cloned plants. Tissue culture methods present a widely exploited potential for rapid clonal propagation of azadirachtin high levels producing genotypes over seed propagation. Several studies have been undertaken to develop tissue culture protocols for neem. In vitro multiplication of neem was described using nodal segments (Yasseen, 1994) and leaf explants (Eeswara et al., 1998). Neem regeneration was reported from callus derived from the leaves (Narayan and Jaiswal, 1985), anthers (Goutam et al., 1993) and cotyledons (Rodrigues et al, 2009).

The main objectives of these works were the analysis effects of the initial explants (with or without cotyledon) on in vitro shoot tip development. Seed lines development characterization and regeneration system (direct or indirect, with callus formation) were also analyzed.

\section{MATERIALS AND METHODS}

Immature fruits of $A$. indica were collected from two selected mature tree in Agronomic Institute of Pernambuco (IPA). The seeds were collected with $2 / 3$ of mature seeds size. The seeds were identified with different letters to distinguish donor plant (plant A and plant B). This individual was previously identified (data not presented in this paper) with the best level of insecticide (azadiractin A) production.

\subsection{Desinfestation}

Freshly collected immature fruits were washed thoroughly with water and also surface sterilized with ethanol 70\% (1 min.) followed by sodium hypochlorite $5 \%$ solution ( $10 \mathrm{~min}$.) and washing with sterile water for three times.

\subsection{Effect of cotyledon present on embryo in vitro development}

The importance of cotyledons on explants initial in vitro development was made using embryos with or without cotyledon. These explants were aseptically incubated in flasks containing DKW medium supplemented with $30 \mathrm{~g} \mathrm{~L}^{-1}$ of sucrose, $7 \mathrm{~g} \mathrm{~L}^{-1}$ of agar agar and $\mathrm{pH}$ of 7.0. After in vitro seed germination, shoot tip of seedlings were dissected out and cultured on Introduction Medium - IM [DKW medium supplemented with $0.225 \mathrm{mg} \mathrm{L}^{-1}$ of 6-benzyl aminopurine (BAP), $30 \mathrm{~g} \mathrm{~L}^{-1}$ of sucrose, $7 \mathrm{~g} \mathrm{~L}^{-1}$ of agar agar and $\mathrm{pH}$ of 5.7], during one week. All shoot tips obtained from this initial culture were analyzed (plant size, leaf number, root development).

\subsection{In vitro behavior of shoot tips from different seeds}

In this experiment, embryo with cotyledons were used as initial explant. Afther in vitro inoculation in aseptic condition, each seed was identified with a leter corresponding to donor plant (A or B) and specific number to avaliate explant behavior durin successive in vitro culture. In this experiment eleven seed from plant donor A and ten seeds from donor plant B were used. All explants obtained from a initial seed shoot tip recived the same identification. After in vitro seed germination, shoot tip of seedlings were dissected out and cultured on DKW medium with hormone alternence exposure. All shoot tips were cultured for one week in HM medium [DKW supplemented with $0,225 \mathrm{mg} \mathrm{L}^{-1}$ of 6-benzyl aminopurine (BAP) $30 \mathrm{~g} \mathrm{~L}^{-1}$ of sucrose, $7.0 \mathrm{~g} \mathrm{~L}^{-1}$ of agar agar and $\mathrm{pH}$ of 5.7] and for tree weeks in HF Medium (HM medium without BAP). These procedure was repeated during six months. The explants were maintained in growth room $\left(25 \pm 2^{\circ} \mathrm{C}\right.$ and $16 \mathrm{~h}$ light period). Every month, all plants from each seed were morphologically characterized (callus presence, callus localization, leaf senescence, plant size, root development). All data were statistically analized. Statitic chi-squared (5\%) and Fisher test (Pimentel-Gomes, 2009). 


\subsection{Organogenic callus potential evaluation}

The indirect callus regeneration potential was also analyzed. All callus developed in the basal part of the shoot tips were transferred and kept on HF medium (without BAP). The explants were maintained in controlled environment growth room $\left(25 \pm 2^{\circ} \mathrm{C}\right.$ and $16 \mathrm{~h}$ light period $)$. Transferred to fresh medium was made each 30 days. All shoot tips obtained from callus were cultured as shoot tips obtained from seeds (one week on HM medium and tree weeks on HF medium). Every month, all plants from callus were morphologically characterized (callus presence, callus localization, callus size, leaf senescence, plant size, root development).

\subsection{Acclimatization}

After six months, all shoot tips, obtained from nodal segments and from callus, were transferred to the rooting medium supplemented with $0,4 \mathrm{mg} \mathrm{L}^{-1}$ of IBA.

These platelets were transplanted into small pots contained soil and sand and were maintained in greenhouse with irrigation system. In that condition the platelets were watered every day to be prepared to be transplanted to the field. After one month in a greenhouse, three plant lines were chosen by chance and, the stem diameter, leafs number and plants high were measured.

\section{RESULTS}

The shoot induction was almost the same between embryos with our without cotyledon. However, shoot development was significantly influenced by the cotyledon presence or absence (Figure 1). Shoot tip explants from embryos with cotyledons showed a higher shoot development $(8.5 \mathrm{~cm})$ after 30 days than embryos without cotyledons $(2.0 \mathrm{~cm})$. These results indicate that some substances in the cotyledons are essential to the initial soot tips best development.

The callus development was observed in $90.5 \%$ explants. However, callus development was significantly influenced by the seed line. Some seed lines presented a faster callus development. Callus development occurred in the soot tip base more frequently $(86.3 \%)$ than in the stem (23.2\%) (Table 1).

Root development during micropropagation (Table 1) was not frequent. Only $19 \%$ of seed lines presented

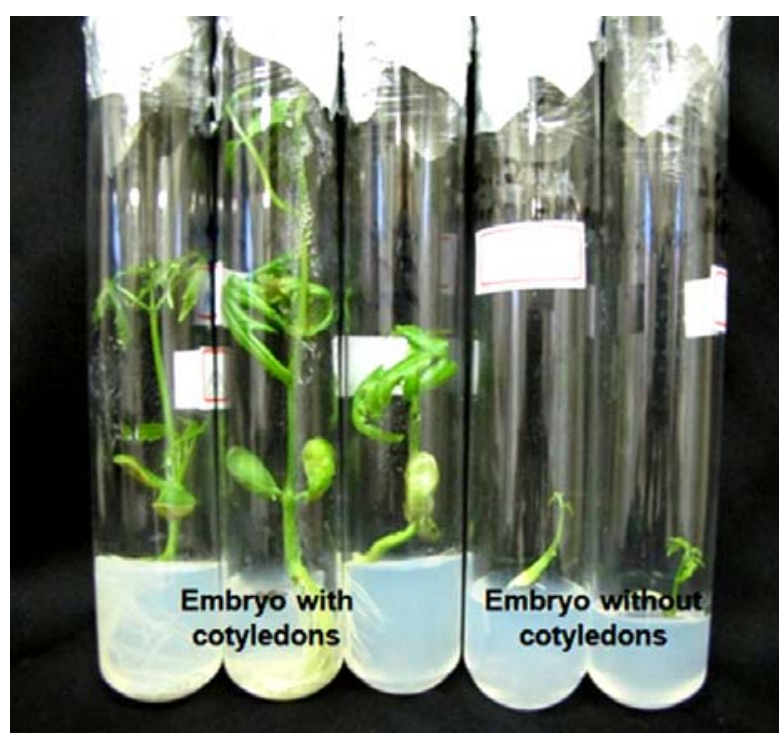

Figure 1 - Difference in the in vitro explant development of neem (A. indica) between embryos with and without cotyledons

Figura 1 - Diferença no desenvolvimento in vitro de explantes de nim (A. indica) observada entre embriões com e sem cotilédone.

root. However the less frequent characters were callus absent and leaf senescence $(9,52 \%)$.

If a seed line developed callus in the stem, all explants produced from this initial explant apresented the same in vitro response. This response was observed in all characteristic analysed. This result indicate that is probable that in vitro response of neem shoot tips is influenciated by genetic characteristic (Figure 2).

The results obtained with chi-squared test ( $5 \%)$ demonstrated no significant difference in normal size plants between line A and B with the percentage values of 63.6 and $70 \%$ respectively. No significant difference was also observed in the variable callus at the base of the plants between lines A and B, 72.2 and 100\% respectively. All the other characteristics differ between donnor plant A and B (Figure 3).

The medium shoot tip production in seed lines from the donor plant A was 30 shoot tips. On the other hand, the medium shoot tip production in seed lines of donor plant B was 58 shoot tips.

Callus isolates from shoot tips base and maintained in hormone free medium started regeneration process

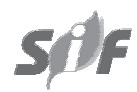

Revista Árvore, Viçosa-MG, v.39, n.3, p.439-445, 2015 
Table 1 - Seed lines development characteristic observed during plant micropropagation, according donor plant (A or B).

Tabela 1 - Características do desenvolvimento das linhagens de sementes observadas durante a micropropagação de plantas, de acordo com a planta matriz.

\begin{tabular}{cccccc}
\hline $\begin{array}{c}\text { Donor } \\
\text { plant }\end{array}$ & $\begin{array}{c}\text { Normal } \\
\text { plant high }\end{array}$ & $\begin{array}{c}\text { Leaf } \\
\text { atrophy }\end{array}$ & $\begin{array}{c}\text { Root } \\
\text { development }\end{array}$ & $\begin{array}{c}\text { Basal } \\
\text { callus }\end{array}$ & $\begin{array}{c}\text { Stem with } \\
\text { callus }\end{array}$ \\
\hline A & $66,6 \%$ & $36,4 \%$ & $27,3 \%$ & $72,2 \%$ & $36,4 \%$ \\
B & $70 \%$ & $10 \%$ & $10 \%$ & $100 \%$ & $0 \%$ \\
sedium value & $68,3 \%$ & $23,2 \%$ & $18,6 \%$ & $86,3 \%$ & $23 \%$ \\
\hline
\end{tabular}
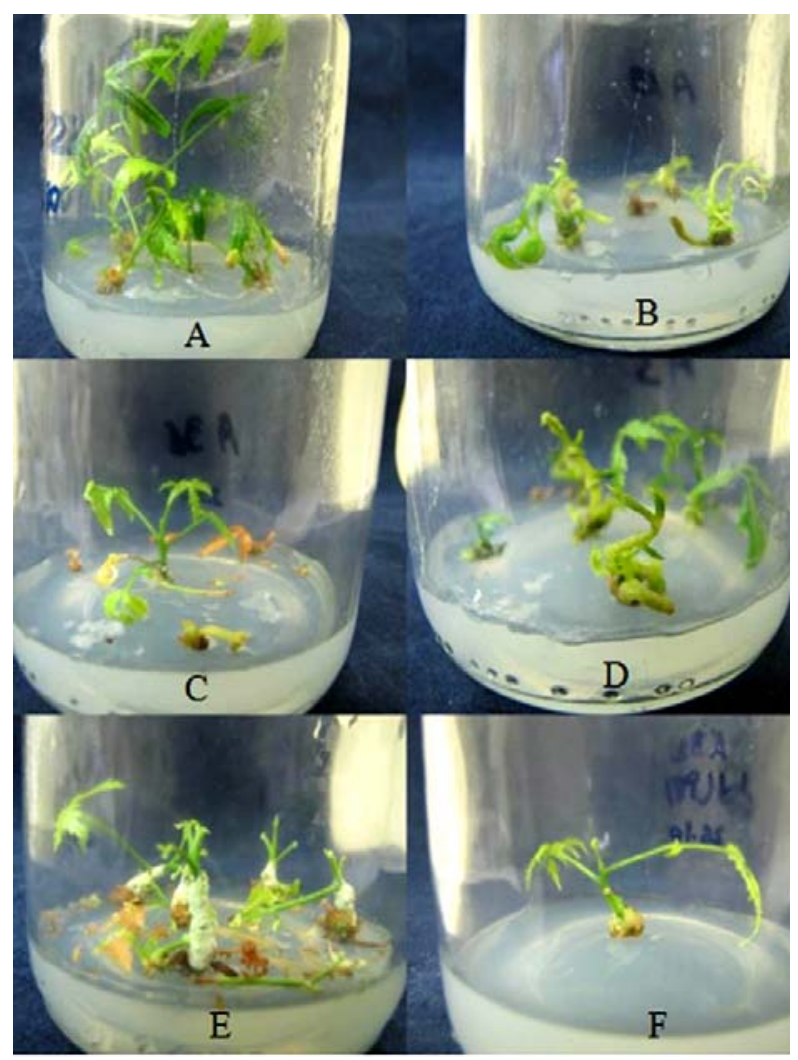

Figure 2 - Neem in vitro development behavior. A and B - Normal plant size and dwarf plants respectively, $\mathrm{C}$ and $\mathrm{D}$ - Senescence of leaves and leaves atrophy, $\mathrm{E}$ and $\mathrm{F}-$ Example of callus location.

Figura 2 - Desenvolvimento in vitro de nim; A e B-Plantas com tamanho normal e plantas anãs, respectivamente; Ce D-Senescência das folhas e atrofia das folhas; e E e F - Exemplo da localização dos calos.

one month after shoot tip excision. Callus regeneration capability was observed in $75 \%$ of total callus formed.

The number of regenerated shoot tips from callus was different. Multiple shoot formation was observed in $55 \%$ callus. Single shoot tip formation was observed

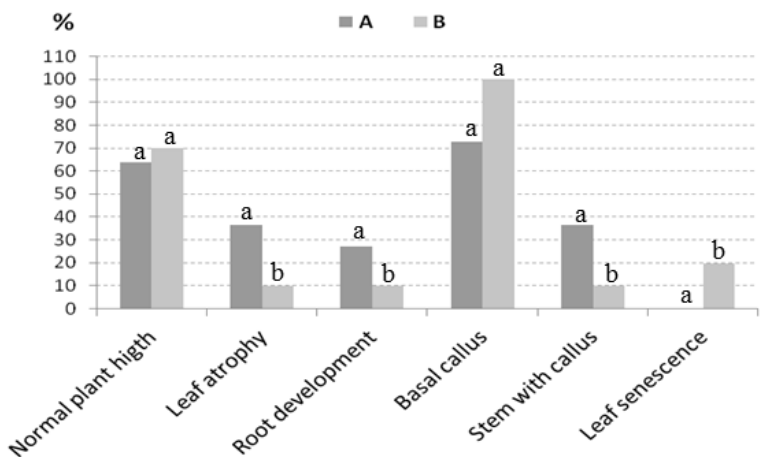

Figure 3 - In vitro response of neem from the two seed donor plants (A and B). Statistical differences were found in leaf atrophy, root development, stem with callus and leaf senescence. In the comparision of each characteristics, columns with same letter have no statistical difference.

Figura 3 - Resposta in vitro de nim a partir de duas plantas doadoras de sementes (A e B). Foram encontradas diferenças estatísticas na ocorrência de atrofia de folhas, no desenvolvimento das raízes, em caules com calos e na senescência foliar. Na comparação de cada uma das características, colunas com a mesma letra não apresentam diferença estatística.

in 5\% callus and no shoot tip formation was observed in $10 \%$ callus (Figure 4 ). Non regenerative callus developed green color but no sing of regenerative process were observed.

Root development occurred in all plants (obtained from shoot tip propagation and from callus) maintained in rooting medium for 45 days.

After one month in the greenhouse, no significant difference between plants propagated from shoot tips and plants obtained from callus was observed. The medium plants high in different plant lines were between $11.7 \mathrm{~cm}$ and $13.0 \mathrm{~cm}$. The medium leaf number was between 8.9 and $9.3 \mathrm{~cm}$. The medium stem diameter was between 2.7 and $3.3 \mathrm{~cm}$.

Revista Árvore, Viçosa-MG, v.39, n.3, p.439-445, 2015 


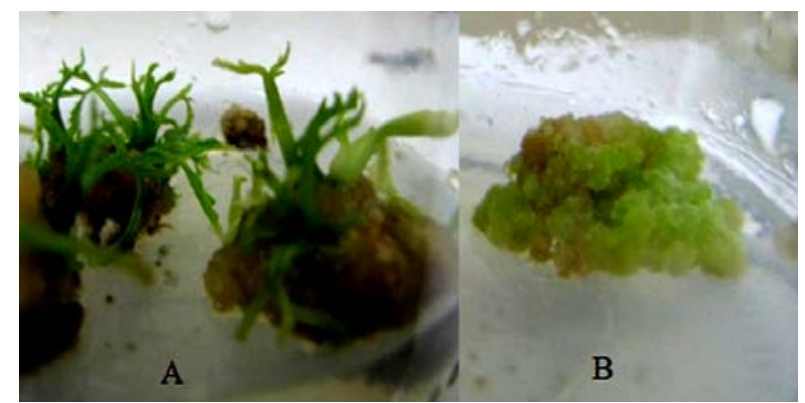

Figure 4 - In vitro neem callus development. A- Organogenic callus with multiple shoot tips, B - Non organogenic callus.

Figura 4 - Desenvolvimento in vitro de calos de nim. ACalo organogênico com múltiplos ápices caulinares e B-Calo não organogênico.

\section{DISCUSSION}

Shahim-uz-zaman et al. (2008) obtained plants 2.79 $\mathrm{cm}$ high after 70 days. These results confirm that cotyledon presence indeed have an influence on shoot tip initial development. As such, the initial culture of neem embryos with cotyledons can improve the quality of shoot tips for micropropagation.

Normal shoot tip development (approximately 7 $\mathrm{cm}$ long after 30 days) was observed in $66.7 \%$ of seed lines (Table 1 and Figure 3 ). Shorter shoot tips (approximately $2 \mathrm{~cm}$ long), observed in about $23.8 \%$ of seed lines, were also micropropagation-viable. However, micropropagation rates were lower in these seed lines. According to Reddy et al. (2009), high-hormone concentrations hindered shoot tip elongation, resulting in dwarf plants with reduced leaves. Therefore, differences in hormone concentrations between plant lines can be responsible for these results.

These results showed that the most common pattern in neem development in vitro was a plantlet with a shoot tip about $7 \mathrm{~cm}$ long and callus development at the base of the shoot tip. Shahim-uz-zaman et al. (2008) were not able to obtain neem plants in hormone-free medium. However, the explants subjected to alternating hormone exposure (one week in hormone presence followed by three weeks in hormone absence) did not demonstrate any interference on shoot tip micropropagation. This result indicates that even a small exposure to BAP was effective in the explants' regenerative induction.
There was no statistical difference in normal-plant size occurrence between plants from either A and B lines, as indicated by the Fisher test. This shows that neem micropropagation tends to produce tall, normal plants. The Fisher test also indicates that callus occurrence at the base of the stem varies according to the donor plant, in which the highest percentage was obtained in seed line B (100\%) in contrast to seed line A $(72.2 \%)$ (Figure 3). This indicates that this feature can be influenced by the donor plant from which the explants are obtained.

The number of shoot tips also differs between seed lines. These differences can be the result of different development characteristics and genetic background. Therefore, each seed is provided with a particular genetic combination that may influence in vitro response.

This response can be influenced by donor plant genetic background, but, as an open pollinated plant, neem seed genetic combination seems to be the most important factor. The differences in the amount of shoot tips produced from seeds from the same donor plants (Ex. A-6 produced 8 shoot tips and A-38 produced 108 shoot tips) could be the strongest evidence of the genetic background influence on in vitro development. It was also observed that seed lines from donor plant $\mathrm{B}$ presented a better micropropagation development. These results indicate that micropropagation potential can be strongly influenced by donor plant's characteristics.

Several characteristics such as leaf atrophy, root development, stem with callus and leaf senescence may also be influenced by the donor plant. However, normal plant height and basal calluses are the more frequently obtained features in vitro when different donor plants are used (Figure 3).

These results can also indicate that genetic background may be the main reason for the divergence of in vitro response observed in this work. Differences in vitro response can be also due to donor plant's age. The importance of juvenile explants in micropropagation of Pinus roxburghii was reported by Arya et al. (2012).

Callus isolates from the base of shoot tips and kept in a hormone-free medium started the regeneration process one month after shoot tip excision. Callus regeneration capability was observed in $75 \%$ of total calluses formed.

Revista Árvore, Viçosa-MG, v.39, n.3, p.439-445, 2015 
The organogenic potential of neem calluses was not always present in this work. Rodrigues et al. (2009) also recommended callus texture as a good parameter for selection of organogenic calluses. However, no correlation on callus texture and organogenic potential was observed in this experiment.

Rodrigues et al. (2009) obtained neem callus regeneration using medium supplemented with 2.0 $\mathrm{mg} \mathrm{L}^{-1}$ BAP. However, in the present experiment, plants regenerated from calluses were obtained in hormonefree medium.

Since neem calluses are easy to obtain, they could be used as a source of important secondary metabolic compounds. Raficq and Dahot (2010) observed a significant increase in azadirachtin-related limonoids production with the change of sucrose or glucose concentration.

These results indicate that root development was easily obtained in micropropagated neem plants. This result could be an effect of a favorable action of IBA alone in neem root development. According to Cha-um et al. (2003), rooted plantlets with IBA were also acclimatized under low RH\% (Relative Humidity) conditions and demonstrated a higher physiological adaptation. These results indicate that the Azadiratcha genus seems to be responsive to IBA. As such, a welldeveloped root system allows for successful acclimatization and final establishment in field.

All callus-isolated plants had a similar development compared to shoot tip plants in propagation medium and in rooting medium.

There were no difficulties in plant acclimatization. The number of plant losses was less than $3 \%$, indicating that rooted neem plant from in vitro cultures are indeed viable in vivo. At the end of the acclimatization process there was no visual difference between plants obtained from shoot tip propagation and from callus regeneration. A satisfactory acclimatization of regenerated neem was also obtained in Azadirachta siamensis by Cha-um et al. (2003).

After spending one month in the greenhouse, several aspects showed no significant difference between plants propagated from shoot tips and plants obtained from calluses. These results may indicate that, despite organogenic processes (direct or indirect), the plants presented the same resembling characteristics in the greenhouse.

\section{CONCLUSIONS}

The present experiments have shown that it is possible to induce shoot differentiation and complete plant development from shoot tip and callus explants of neem. The initial in vitro development stage was influenced by cotyledons presence. The propagation potential can be influenced by donor plant used as explant source. Plants obtained from callus and from the shoot tip propagation did not present in vivo differences (green house) indicating that both regenerative processes are viable to in vitro plant production.

\section{ACKNOWLEDGEMENT}

Special thanks to IPA (Instituto Agronômico de Pernambuco) and MCTI (Ministério de Ciência, Tecnologia e Inovação).

\section{REFERENCES}

ARYA, A.; KUMAR, S.; KASANA, M.S. Effect of plant growth regulators and $\mathrm{pH}$ of medium on in vitro regeneration of Pinus roxburghii sarg.

Indian Journal of Fundamental and Applied Life Sciences. v. 2, n. 4, p.66-75, 2012.

CHA-UM, S.; MOSALEEYANON, K.; SUPAIBULWATANA, K.; KIRDMANEE, C. A More Efficient Transplanting System forThai Neem (Azadirachta siamensis Val.) by Reducing Relative Humidity. ScienceAsia, v.29, p.189196, 2003.

EESWARA, J.P.; STUCHBURY, T.; ALLAN, E.J.; MORDUE, A.J. A standard procedure for the micropropagation of neem tree (Azadirachta indica A. Juss.). Plant Cell Reports, v.17, p.215-219, 1998.

GOUTAM, V.K.; NANDA, N.; GUPTA, S.C. Development of shoots and roots in anther derives callus of Azadirachta indica A. Juss. Plant Cell and Tissue Organ Culture, v.34, n.1,p.13-18, 1993.

NARAYAN, P.; JAISWAL, V. S. Plantlet regeneration from leaflet callus of Azadirachta indica A. Juss. Journal of Tree Science, v.4, n.1, p.65-68, 1985. 
PIMENTEL-GOMES, F. Curso de estatística experimental. Piracicaba: FEALQ, 2009. p.287-296.

RAFIQ, M.; DAHOT, M.U. Callus and azadirachtin related limonoidsproduction through in vitro culture of neem (Azadirachta indica A.Juss).

African Journal of Biotechnology, v.9, n.4, p. 449-453, 2010.

REDDY, A.R.; BAVAJI, M.; RAO, J.V.S.

Micropropagation of Azadirachta indica A. Juss.via cotyledonary nodes. Indian Journal of Biothechnology, v.5, p.309-311, 2009.
RODRIGUES, M.; PAIVA, R.; NOGUEIRA, R.C.; MARTINOTTO, C.; SILVA JÚNIOR, J. M. Morfogênese in vitro de Nim a partir de explantes cotiledonares. Revista Árvore, v.33, n.1, p.21-26, 2009.

SHAHIN-UZ-ZAMAN, M.; ASHRAFUZZAMAN, M.; HAQUE, M.S.; LUNA, L.N. In vitro clonal propagation of the neem tree (Azadirachta indica A. Juss.). African Journal of

Biotechnology, v.7, n.4, p.386-391, 2008.

YASSEEN, Y.M. Shoot proliferation and plant formation from neem with thidiazuron. Horticultural Science, v.29, n.5, p.505-515, 1994. 